\title{
ORGANIZATIONAL CLIMATE AND EMPLOYEE COMMITMENT IN NIGERIAN DEPOSIT MONEY BANKS
}

\author{
By \\ AHMED, Mariam Ahuoiza \\ Department of Business Administration \\ Nasarawa State University, Keffi \\ ahuoiza17@yahoo.co.uk
}

\begin{abstract}
The study was motivated by the problem of high employee turnover rate in the Nigerian banking industry. The study sought therefore, to assess the effect of organizational climate on employee commitment in the Nigerian Banking sector. The study was restricted to employees of Nigerian Banks in the Abuja regional offices. The study adopted the survey research design, primary data was used for the study and collected electronically through a structured questionnaire coded into Google forms. Regression technique was used to analyze the data collected. From a purposively selected sample of 384 respondents. The study found that organisational commitment has a positive and significant effect on employee commitment in the Nigerian banking sector and recommends that collaborative work climate, open communication channels across the firm, and employee engagement in decision making in order to boost commitment of the employees in the organization.
\end{abstract}

Keywords: Employee Commitment, Organizational Climate, Nigerian Banks

c) 2020 the Author(s). Published by OASIS Journals. Open access under CC BY-NC-ND License

\section{Introduction}

Commitment is agreed to be a vital factor in organizations because it was found to enhance organizational citizenship behavior, employee performance, and more involvement in work (Czaja, 1999). In most cases, commitment is related either to work, career, or the organization (Guney, Diker, Guney, Ayranci \& Solmaz, 2012; Wu \& Lui, 2006). Research studies have established that there is a positive impact of organizational commitment on employees' job performance and the organizational performance (Gasic \& Pagon, 2004; Iqbal, 2010; Naqvi et al., 2011).

In Nigeria today, workplace is enveloped by the fear of downsizing, trouncing of job security, vast change in technology, and the stress of having to do extra with less established variety of caring, feisty workplace that will ignite worker commitment. Based on the backdrop, it seems pertinent to know and comprehend more about the 
organizational commitment. According to Mowday, Porter, and Steers (1982) "a strong aspiration to remain as a member of a particular company, a readiness to exert high-levels of effort on behalf of the organization, and a distinct belief in, and acceptance of the values and goals of the company means organizational commitment."

Researchers in the areas of organizational behaviour and Human Resource Management treat satisfaction and commitment as different attitudes. They refer to organizational commitment as the degree to which a worker identifies with an organization and its objectives and wishes to sustain affiliation in the organization. In the light of the new environment that includes downsizing; telecommunity, merger and acquisition, globalizations and diversity, organizational commitment have resurfaced as a very important topic of the study (Luthans, 2008).

Furthermore, studies have found that organizational commitment, especially normative commitment has positive relationship with employees' performance in organizations and other industries (Irefin \& Mechanic, 2014; Memari, Mahdieh, \& Marnani, 2013). In other words, employees tend to perform better based on their sense of obligation and loyalty towards their organizations. Therefore, the lack of commitment from employees in the organization increases their intent or act to leave and reduce the overall organizational performance.

Today, Nigerian banks are challenged by the lack of commitment from employees due to their choices to leave the organization, implying a high turnover rate in the industry. Employees' turnover describes the ratio of employees who have been replaced at a certain period of time (Rouleau et al., 2012; Price, as cited in Abdali, 2011). Studies have suggested that employee turnover is a growing issue (Deloitte, 2014; Romualdez et al., 2011).

There are several reasons for the phenomenon of employees' turnover in the banking sector. Around the world, especially in developing countries, the reasons for the employees to leave their organizations are the push and pull factors (WHO Report, 2006). Pull factors include better remunerations, better standards of living, gaining experiences, and upgrading qualifications. Furthermore, push factors include lack of facilities, lack of promotion, ineffective management, excessive work stress, lack of 
training, and absence of career development. The employees' decisions to quit organizations are also linked to the level of stress, empowerment, and respect within the organizations (Peterson, 2009).

It must be noted that the level of commitment of employees affects customer service quality, the employees' productivity, and their effectiveness, as well as the organization's overall performance (Al-Hassumi, 2008). The purpose of this study is consequently to contribute to the understating of the determinants of employee's commitment, with particular reference to organizational climate and its effect on commitment of employees in the Nigerian banking sector. The study does this by statistically testing the following research hypothesis:

Ho1 Organizational climate has no significant effect on employees' commitment in the Nigerian banking sector

The study sought to assess the effect of organizational climate on employee commitment in the Nigerian Banking sector. The study was restricted to employees of the Nigerian banking in Abuja, Nigeria. This is because Abuja is the Federal Capital Territory of the country and the banks all have major regional or head offices located in Abuja. The study was a cross sectional one conducted in the year 2021. The study was also restricted to employees' commitment as the dependent variable of the study, while organizational climate was the independent variable.

\section{Conceptual Review}

\section{Concept of Organizational Climate}

Organizational climate describes how employees perceive particular characteristics of their employing organization. For this study, organizational climate includes dimensions such as the leadership style, the communication level, and the employees' participation in the decision making. A study concluded that organizational climate influences healthcare employees' level of commitment till 60\% (Liou \& Cheng, 2010). The healthcare workers tend to decide to leave their jobs according to their degree of agreement with the level of trust, the flow of information, and the leadership style. So, organizational climate has an influence on the employees' behaviors and attitudes towards the organization, and therefore on their commitment to the organizations (Adjei-Appiah, 2008). 
Organizational communication refers to the process and means the management transfers the information (goals, objectives, and strategies) to the employees (Boon et al., 2006). The presence of a healthy climate in the organization helps to build, establish, and maintain the organizational commitment of the employees (Noordin et al., 2010). Hence, communication is positively related to employees' commitment in the organization. According to a research done among nurses in Malaysia, communication is the dominant variable that has a significant effect on employees' commitment (Boon et al., 2006). Further, several studies concluded that there is a positive relationship between the leadership styles and the organizational commitment (Lai, 2004; Tseng et al., as cited in Lee, Lee and Lin, 2014; Loke, 2001). Also, the findings on a study conducted on Egyptian nurses emphasized on the fact that it is important to involve employees in decision making and empower them. So, the participation of employees to decision making enables to increase the employees' commitment towards the organization (El-Salam et al., 2008).

\section{Concept of Employee Commitment}

Commitment is defined as the connection between the organization and the employees. It is also described as willingness and steady forces that determines and maintains the attachment of an individual to a particular organization (Vance, 2006). In other words, it is a psychological bond that is characterized by the members' feeling of attachment, obligation, and loyalty to a given organization. Commitment also describes the level of employees' acceptance of the organization's goals and the willingness they have to work towards these goals (Manetje \& Martins, 2009).

According to Meyer and Allen (as cited in McMahon, 2007), organizational employees' commitment has three main aspects: affective, continuance, and normative commitments. Affective commitment is defined as the emotional and sentimental attachment an individual has towards an organization. It is also considered as the level to which employees identify themselves with the organization and its goals to maintain their membership (Modway et al., as cited in Azeem, 2010). The characteristics of the affective commitment include three elements: the belief and the acceptance of the organization's values and objectives; the willingness to work towards the organization's goals, and the aim to maintain the relationship with the 
organization (Porter et al., as cited in Ismail, 2012). The continuance commitment is linked with the costs related to the alternatives to leave the organization. In other words, the employees remain in the organization because the alternatives are inexistent or not certain. Concerning the normative commitment is the moral obligation an individual has to remain in the organization. So, the employees are loyal and consecrated to the organization as a duty and obligation (Ismail, 2012).

\section{Empirical Review}

\section{Organizational Climate and Employee Commitment}

Gitau and Monari (2019) carried out a study titled "determinants of employee commitment in constitutional commissions in Kenya". The general objective of their research was to identify determinants of employee commitment in constitutional commissions in Kenya. A descriptive cross-sectional survey design was adopted. The target population was 4,771 employees. Simple random sampling was first conducted and then followed by random stratified sampling. A sample of 380 was used. The study relied on primary data collected using structured questionnaires which were pretested to ensure both validity and reliability. Data analysis was done by using descriptive and inferential statistics. The study found that compensation and reward had a significant effect on employee commitment. It was also established that work environment had a significant effect on employee commitment.

Shukla and Sinha (2013) in their study examined Employee's Turnover in banking sector with total sample size 44, out of which 22 samples was collected from employee's working in bank from more than two years and 22 from those who were working from less than two years. The questionnaire consists of 23 questions. Initial 8 questions are related with employee's basic information where as in next 15 questions, 5 questions from each parameter namely work environment and career development and job satisfaction were asked. As evident from the results the prime factors for employee's turnover in their respondent banks are job satisfaction and work environment. The high significance level for both variables show that, whether there is a salary compensation or not, employees have a gigantic desire to opt for new ventures in need of better work environment and job satisfaction. Comparative to above two variables the career development is having lesser but a quiet considerable 
significance. The people who counted career growth as their prime force for turnover have put a saddle on availability of opportunities and management relations as subprime forces, but they turnover for new venture for better wages or salary compensation.

Osemeke (2016) focused their study on the identification of determinants of organizational commitment and employee job satisfaction. It was viewed as one of the basic concepts describing the relationship between an employee and an organization. In the paper, determinants of organizational commitment, factors conditioning development of three organizational commitment components and various variables responsible for employee satisfaction were discussed. The variables included Organization development factors, Job security factors, Work task factors, Policies of compensation and benefit factor and opportunities in the organization. Other factors discussed which give satisfaction to employees include: promotion and career development, equitable rewards and supportive colleagues; also discussed are the various ways by which one can improve employee satisfaction. The main objective of this study was to discuss the above mentioned variables and examine the major determinants of organizational commitment and employee job satisfaction and highlight the factors that can enhance employee's job satisfaction. This paper adopted the exploratory and content methods analysis of various relevant literatures to review the concepts of organizational commitment and employee job satisfaction. The paper recommended that Organizational managers should try their best to evaluate why employees leave or what kindles their dissatisfaction.

Newaz (2007) conducted a study on employee's perception regarding turnover decision. The purpose of this study was to find out the perceived significant causes of leaving of employee's from different management hierarchy in the existing financial institutions of Bangladesh and its probable solutions. The findings revealed that in general, job recognition and appreciation were rated as the most important factors and desire to return to school is the least important factor for leaving from an organization. The other eight items were assigned in between the two positions. Easy availability of equal or better paying jobs is second perceived important factor to the employee's. Unhappiness with job demands/requirements and friction/conflict with supervisor 
or co-worker have got the same score as perceived important factor for switching. Unhappiness with job demands/requirements has been rated as the most important factor by mid-level of management and easy availability of equal or better paying jobs has been rated as the most important factor by entry-level of management. Job recognition and appreciation were rated as the most important factors by top level of management.

The studies above all made contributions to knowledge on the phenomenon of employees' commitment and turnover. However, all the previous studies were conducted in different locations and at different times using varying methodology. This study contributes to the body of academic knowledge by bridging the gap in research and providing the most recent findings and recommendations, particularly regarding the effect of organizational climate on employee commitment in the Nigerian banking sector with particular reference to deposit money banks' employees in Abuja, Nigeria.

\section{Theoretical Framework}

\section{Expectancy Theory}

Human beings by nature are driven by stimuli which determine their destiny (Desler \& Varkkey, 2013). These stimuli are what drive people to do what they do or what they are capable of doing because of the returns they expect after doing that act. On the converse, it is what individuals would rather not do in order to achieve certain heights. This is what underpins this theory. Where an individual anticipates gaining something after undertaking a certain action inspires that individual to continue pursuing that same course. Where the expectations fall short of what was anticipated, this then marks a turning point for the individual where the person is persuaded not to continue exerting the same effort to achieve the anticipated objectives (Torrington et al, 2014).

\section{Methodology}

This study adopted the survey research design using a structured questionnaire as the main tool of data collection. The population of the study covers all employees of the Nigerian banking industry in Abuja which is unstated or infinite in Nature. The study 
therefore employed purposive sampling technique to select the respondents based on specific criteria set for the study. These criteria include: a) employee must have worked in the bank for a minimum of three years, b) employee must still be an employee of the bank, c) availability to take survey. However a minimum sample size of 384 was adopted using the formula for sample size attainment from undefined population by the formula by Saunders et al (2009).

Primary data was used for the study and the data was collected using the questionnaire coded into Google forms. The respondents were approached with the questionnaire electronically through their emails, Facebook and WhatsApp. The study adopted regression analysis statistical technique to analyse the data for the study with a view to ascertaining the cause and effect relationship between the research variables using the following regression model:

$\mathrm{EC}=\beta_{0}+\beta_{1} \mathrm{OC}+\mathrm{e}$

Where:

$\mathrm{EC}=$ Employee Commitment (Dependent Variable)

$\mathrm{OC}=$ Organisational Climate

$\beta_{0}=$ Constant $/$ Intercepts

$\beta_{1}, \beta_{2}$ and $\beta_{3}=$ Parameters of determination

$\mathrm{e}=$ Margin of error

\section{Findings}

Table 1: Extract of Regression Result

\begin{tabular}{lllllll}
\hline Independent & Dependent & Coef. & P-value & F-Stat & F-Stats & R- \\
Variables & Variable & $(\beta)$ & $\mathbf{( S i g . )}$ & & $\begin{array}{l}\text { P- } \\
\text { value }\end{array}$ & Square \\
& & & & & \multicolumn{2}{c}{ valu } \\
\hline OC & EC & 0.613 & 0.000 & 74.211 & 0.000 & 0.483
\end{tabular}

\section{Source: Researcher's Computation, 2021}

The statistical decision rule of $\mathrm{p}$ - value states that the Null hypothesis should be maintained if p-value is greater than alpha value (i.e. level of significance which is 0.05) otherwise it should be rejected while the Alternative hypothesis is adopted. 
Table 1 shows that the regression model is fit to be used for the study as the F-stats is 74.211 with a p-value of 0.000 . The table also indicated the R-square which is used to determine the variability in the dependent variable (employee commitment) that can be accounted for by a change in the independent variable (organisational climate).

The R-square value of $0.483(48.3 \%)$ implies that the variability changes in employee commitment in the Nigerian Banking sector that can be accounted for by the organisational climate is approximately $48.3 \%$ while the remaining can be accounted for by other factors not captured in the regression model of this study.

In table 1 also, it can be observed that the regression coefficient for gender diversity is 0.613 with p-value of 0.000 which is less than alpha value $(0.05)$ therefore, the null hypothesis is rejected. This implies that organisational commitment has a positive and significant effect on employee commitment in the Nigerian banking sector, Abuja, Nigeria. This implies that the better the organisational climate, the better the commitment employees to the banks the work for, particularly in Abuja, Nigeria.

\section{Conclusions and Recommendations}

From the above findings, the study concludes that organizational climate contributes significantly to the commitment level of employees in Nigerian Banks, particularly in Abuja, Nigeria. This means that the organizational climate in the context of this study which includes the leadership style, the communication level, and the employees' participation in the decision making, plays a significant role in building employees commitment in the sector.

In line with the findings and conclusions, the study therefore recommends that the ownership and management of the banks in Nigeria should make organizational climate a serious matter of top priority when formulating and implementing their strategies, particularly as it affects employees. There should be a collaborative work climate, open communication channels across the firm, and employee engagement in decision making in order to boost commitment of the employees in the organization. 


\section{References}

Al-Hussami, M. (2008). A study on nurses' job satisfaction: The relationship to organizational commitment, perceived organizational support, transactional leadership, transformational leadership, and level of education. European Journal of Scientific Research, 22(2), 286-296.

Abdali, F. (2011). Impact of employees' turnover on sustainable growth of organization in computer graphic sector of Karachi, Pakistan. Afro Asian Journal of Social Sciences, 2 (2.4), 1-27.

Adjei-Appiah, S. (2008). Organizational climate and turnover in the health sector: The case of the Korle-Bu teaching hospital in Ghana; (Unpublished master thesis). University of Waterloo. Retrieved from https:/ / uwspace.uwaterloo.ca/bitstream/handle/10012/3987

Azeem, M. (2010). Job satisfaction and organizational commitment among employees in the Sultanate of Oman. Psychology, 1, 295-299. doi:10.4236/psych.2010.14038

Boon, K.O., Safa, M.S., \& Arumugam, V. (2006). TQM practices and affective commitment: A case of Malaysian semiconductor packaging organizations. International Journal of Management and Entrepreneurship, 2(1), 37-55. Retrieved from semiconductor_11.pdf

Czaja, S. (1999). Organizational commitment? What organization? Japanese Journal of Administrative Science, 13(2), 63-70. Retrieved from http://www.jaas.jpn.org/doc/pdf /journal/13_2/01.pdf

Deloitte. (2014). 2014 global health care outlook: Shared challenges, shared opportunities. doi:10.1111/j.1365-2834.2011.0129

Dessler, G., \& Varkkey, B. (2013). Human Resource Management. 12 ed. New Delhi. Mahajal Press.

El-Salam, A., Ibrahim, M., Mohsen, M., \& Hassanein, E. (2008). Relationship between organizational climate and empowerment of nurses in Menoufiya hospitals, Egypt. Eastern Mediterranean Health Journal, 14(5), 1173-1184

Gasic, D., \& Pagon, M. (2004). Organizational commitment in Slovenian Police Force. Policing in Central and Eastern Europe: Dilemmas of Contemporary Criminal Justice, 1-13. Faculty of Criminal Justice, University of Maribor, Slovenia.

Gitau, A. N. \& Monari, D. G. (2019). Determinants of employee commitment in constitutional commissions in Kenya. The Strategic Journal of Business \& Change Management, 6 (2), 2065 - 2078.

Guney, S., Diker, O., Guney, S., Ayranci, E., \& Solmaz, H. (2012). Effects of organizational communication on work commitment: A case study on public agency in Ankara. Business Management Dynamics, 2(4), 18-29. Retrieved from http://bmdynamics.com/issue_pdf/bmd1101276, \%2018-29.pdf

Iqbal, A. (2010). An empirical assessment of demographic factors, organizational ranks and organizational commitment. International Journal of Business and Management, 5(3), 6-27. 
Irefin, P., \& Mechanic, M. (2014). Effect of commitment on organizational performance in Coca Cola Nigeria Limited Maiduguri, Borno State. Journal of Humanities and Social Science, 19(3), 33-41.

Ismail, N. (2012). Organizational commitment and job satisfaction among staff of higher learning education institutions in Kelanta (Unpublished master's thesis). University Utara Malaysia. Retrieved from http://etd.uum.edu.my

Lee, Y. J., Lee, I. C., \& Lin, C. L. (2014). The effects of employees' satisfaction and leadership styles on organizational performance: Organizational commitment as a dual mediator. Asian Journal of Empirical Research, 4(2), 104-124

Liou, S., \& Cheng C. (2010). Organizational climate, organizational commitment and intention to leave amongst hospital nurses in Taiwan. Journal of Clinical Nursing, 19(11-12), 1635-1644.

Loke, J.F. (2001). Leadership behaviors: Effects on job satisfaction, productivity and organizational commitment. Journal of Nursing Management, 9(4), 191-204.

Manetje, O., \& Martins, N. (2009). The relationship between organizational culture and organizational commitment. Southern African Business Review, 13(1), 87-111.

McMahon, B. (2007). Organizational commitment, relationship commitment and their association with attachment style and locus of control (Unpublished master's thesis). Georgia Institute of Technology. Retrieved from https:// smartech.gatech.edu

Memari, H., Valikhani, M., Aghababaee, Z., \& Davali, M. (2013). The effect of positive organizational behavior of the staff on organizational performance, based on the Luthans model in public organizations of Behbahan. Interdisciplinary Journal of Contemporary Reseach in Business, 4(9), 568-583.

Mowday, R.T., Porter, L.W. \& Steers, R. M. (1982). Employee-Organization linkages. New York: Academic Press.

Naqvi, S., Hashmi, A., Raza, A. S., Shaikh, M., \& Zeeshan, A. (2011). Impact of supportive leadership and organizational learning culture as a moderator on the relationship of psychological empowerment and organizational commitment. Australian Journal of Business and Management Research, 1(8), 65-71.

Newaz, M. K., (2007). "Employee Perception Regarding Turnover Decision - in Context of Bangladesh Banking Sector": BRAC University Journal, vol. IV, no. 2 , p. $67-74$

Newman, A., Thanacoody, R., \& Hui, W. (2001). The impact of employee perceptions of training on organizational commitment and turnover intentions: A study of multinationals in the Chinese service sector. International Journal of the Human Resource Management, 22 (4), 1765-1787. doi:10.1080/09585192.2011.565667

Noordin, F., Omar, S., Sehan, S., \& Idrus, S. (2010). Organizational climate and its influence on organizational commitment. International Business $\mathcal{E}$ Economics Research Journal, 9(2), 1-10.

Osemeke, M. (2016). Identification of Determinants of Organizational Commitment and Employee Job Satisfaction. African Research Review, 10(2), 81-102

Peterson, Z. (2009). Job stress, job satisfaction and intention to leave among new nurses. (Unpublished master's thesis). University of Toronto. Retrieved from https://tspace .library.utoronto.ca/bitstream/1807/17817/1/Peterson_Jessica_Z 
Romualdez, A., dela Rosa, F., Flavier, J., Quimbo, S., Lagrada, L., \& David, L. (2011). The Philippines health system review. Health System in Transition, 1(2)

Rouleau, D., Fournier, P., Philibert A., Mbengue, B., \& Dumont, A. (2012). The effects of midwives' job satisfaction on burnout, intention to quit and turnover: A longitudinal study in Senegal. Human Resources for Health, 10(9), 1-14.

Shukla, S. \& Sinha, A. (2013). Employee Turnover in banking sector: Empirical evidence. Journal of Humanities and Social Science (IOSR-JHSS) Volume 11, Issue 5, PP 57-61

Vance, R.J. (2006). Employee engagement and commitment: A guide to understanding, measuring and increasing engagement in your organization. Society for human resource management foundation's effective practice guidelines. Retrieved from http://www.shrm.org/about/foundation/ research/documents

World Health Organization Report. (2006). Working together for health. Retrieved from http://www.who.int/whr/2006/whr06_en.pdf 